\title{
MAS Integration and Controllership Effectiveness: Evidence of a Preparer-User Perception Gap
}

\author{
Barbara E. Weißenberger, Department of Business Administration and Economics, Justus Liebig University Gießen, Germany, \\ E-mail: Barbara.Weissenberger@wirtschaft.uni-giessen.de \\ Hendrik Angelkort, Department of Business Administration and Economics, Justus Liebig University Gießen, Germany \\ E-mail: info.bwl4@wirtschaft.uni-giessen.de \\ Gero Holthoff, Department of Business Administration and Economics, Justus Liebig University Gießen, Germany \\ E-Mail: Gero.Holthoff@wirtschaft.uni-giessen.de
}

\begin{abstract}
Recent evidence suggests that managers establish a positive link between management accounting system (MAS) integration and controllership effectiveness, which is fully mediated by the perceived consistency of financial language. Our paper extends this research by analyzing whether controllers have similar perceptions on MAS design. Testing a series of multi-group structural equation models, we find evidence for a preparer-user perception gap with respect to the mediating impact of a consistent financial language. Our results contribute to the still-ongoing controversial debate on MAS integration by indicating that the effectiveness of MAS design cannot be evaluated solely from an instrumental perspective independent from users'perceptions.
\end{abstract}

JEL classification: $M 41$

Keywords: management accounting system, controllership effectiveness, preparer-user perception gap, structural equation modeling (SEM), survey, multi-group analysis

Manuscript received July 12, 2011, accepted by Rainer Niemann (Accounting) April 4, 2012.

"Improved management accounting information can only come about through a convergence of the perceptions of management accountants and managers..." (Pierce and O'Dea 2003: 287)

\section{Introduction}

In most modern firms, accounting information used for managerial decision-making is provided by specialized agents, i.e., management accountants or as in German-speaking firms typically denoted controllers (Weber and Schäffer 2008). The likely consequence of separating the preparation and use of management accounting information is an incomplete fit between the information desired by the users (i.e., the managers) and the information considered relevant and, therefore, supplied by the preparers (i.e., the management accountants or controllers). Literature provides broad evidence for the existence of so-called preparer-user perception gaps, which are caused by different notions of what constitutes 'good' or 'relevant' management accounting information. Such preparer-user perception gaps may result in detrimental effects in the relationship between managers and management accountants (e.g., Bruns and McKinnon 1993).

In our paper, we take up a research idea originally presented by Pierce and O'Dea (2003), who compared perceptions of managers and management accountants (controllers in our terminology) on management accounting system (MAS) information as well as on management's information needs. However, we transfer this setting into a different institutional context, as our analysis is nested in the fundamental shift of German management account- 
ing practice from a separate towards an integrated structure.

Therefore, our paper deals with the following research question:

Do controllers, i.e., preparers of management accounting information, and managers, i.e., users of management accounting information, have different perceptions regarding the association between MAS integration and controllership effectiveness? Our study builds upon the model and database provided by Weißenberger and Angelkort (2011) (in the following denoted as W/A). Their analysis gives evidence that managers' assessment of controllership effectiveness does not directly depend on the level of MAS integration, but rather on managers' perception of MAS information as being consistent with financial accounting information (i.e., providing a consistent financial language). However, W/A solely focus on the managers', i.e., users', point of view. Thus, their results give no information whatsoever on how controllers as preparers of management accounting information would associate the level of MAS integration with controllership effectiveness. To close this research gap, our paper extends the W/A analysis by establishing a multigroup analysis including also the controllers' viewpoint and thus capturing similarities as well as differences in the perceptions of controllers and managers.

Our paper contributes to the literature in a threefold way:

First, we find evidence for the existence of a preparer-user perception gap within the German shift towards integrated MAS practice. This gap parallels the ongoing theoretical debate about the benefits and shortcomings of an integrated MAS design.

Second, our paper indicates a source of potential frictions between controllers and managers that may result in discontentment or even disuse of the management accounting information provided (Berlant, Browning, and Foster 1990; Bruns and McKinnon 1993). In this context, our results also indicate that relying solely on controllers' viewpoints on MAS design does not necessarily lead to useful accounting information from the management's point of view (Choe 1998).

The evidence provided in our paper therefore supports the notion that MAS design can neither be developed nor evaluated in a purely instrumental fashion without embracing the users' perspective. In that regard, our paper indicates the need for a stronger behavioral focus in research on MAS integration, or, according to Hopwood (1974: 14): "Social and behavioral aspects [of accounting] are just as much an indispensable part of the whole as the more traditional technical aspect".

Finally, the results of our study might be considered in the context of the use of innovations in managerial decision-making and management control. For example, preparer-user perception gaps may also be identified with regard to the theory vs. practical use of value-based performance measures, as “... fieldwork identifies significant inconsistencies in the measurement of EVA and its major components" (Weaver 2001: 51) or with respect to observed "... barriers to the use of sophisticated financial management decision-making techniques [e.g., the use of a modified internal rate of return or a profitability index]," (Trahan and Gitman 1995: 77).

Our paper is organized as follows. In section 2, we provide an overview of the literature used to derive our model and briefly present the W/A benchmark analysis. In section 3, we develop our hypotheses. Section 4 gives an overview of the methodological approach and section 5 provides the empirical analysis, which is conducted using multi-group structural equation modeling (SEM). Finally, in section 6, we discuss the implications of our results.

\section{Literature}

\subsection{MAS integration in German-speaking countries}

Until the 1990s, companies in German-speaking countries traditionally relied on an MAS design based on a so-called 'third set of books' besides the financial and tax accounting records. The resulting separation of financial and management accounting was based on the conceptual framework developed by Eugen Schmalenbach (e.g., Simons and Weißenberger 2008). Such a separate or dual design differs from the common accounting practice in AngloAmerican companies where the MAS design is - at least since the second half of the $20^{\text {th }}$ century - rather integrated, i.e., based on financial accounting data (Johnson and Kaplan 1987; Jones and Luther 2005).

One of the first German companies that openly abandoned the distinction between managerial and financial accounting was Siemens in 1992/93 where 
an integrated MAS design was implemented mainly due to the need for a consistent accounting language for internal as well as for external communication purposes. Ziegler's (1994) seminal paper describing this case instigated a highly controversial debate within the German management accounting literature on the benefits and shortcomings of an integrated MAS design (Simons and Weißenberger 2010).

The debate gained momentum by the fact that the number of companies headquartered in Germanspeaking countries, which decided to base their MAS on financial accounting data, has been increasing substantially since then (e.g., Angelkort 2010; Müller 2006). This development was partly triggered by an important change in the financial accounting environment, which started in 1994 as the first German companies voluntarily adopted the International Financial Reporting Standards (IFRS) (Ewert and Wagenhofer 2007; Jones and Luther 2005). While German GAAP emphasized the perspective of banks and other creditors, the introduction of IFRS established investor-oriented accounting principles and hence a shareholder-oriented perspective, which is deemed more suitable for managerial decision-making (Simons and Weißenberger 2008; Weißenberger/IGC-Arbeitskreis "Controller und IFRS" 2006). So when IFRS became mandatory GAAP for listed companies within the $\mathrm{EU}$ in 2005, the shift towards an integrated MAS design was facilitated for a lot of companies.

Though the shift in German management accounting practice towards MAS integration is thus undeniable, it still remains a matter of discussion in literature. Criticism about MAS integration can be summed up with the call for "different costs for different purposes", a statement originally stemming from Clark (1923: 175). In this context, the main shortcoming of MAS integration is seen in the loss of independence from external GAAP. A separated MAS design allows the use of non-GAAPbased accruals for internal planning, budgeting and performance measurement, thus enabling companies to flexibly employ accounting concepts such as imputed costs (e.g., opportunity costs) to cope with a diverging array of decision-making and control problems. Hence, critics claim that the flexibility to provide 'different costs for different purposes' is not to be abandoned for the sake of uniformity and lesser complexity (e.g., Pfaff 1995; Schweitzer and Ziolkowski 1999).
Despite this criticism there is also a comprehensive strand of literature backing up the use of integrated MAS designs. One of the main advantages is seen in providing 'one version of the truth', i.e., providing a coherent internal and external viewpoint on a company and thus supporting a common financial perspective. For example, several standards or principles within the IFRS have been identified that are appropriate not only for financial accounting purposes, but also for internal decision-making and control purposes. These are, e.g., conservatism (Wagenhofer 1996), fair value accounting (Ewert 2006), or the valuation of construction contracts (Arnegger and Hofmann 2007). Moreover, arguments in favor of an integrated MAS design are the lower maintenance costs compared to a dual structure and the higher reliability of a financial accounting basis (Ewert and Wagenhofer 2007).

Notwithstanding the still-ongoing academic debate, several empirical surveys show that by now numerous major German companies have realized an integrated MAS design (for a review of these studies see Simons and Weißenberger 2010). While there is evidence that from the viewpoint of managers the integration has a positive influence on controllership effectiveness (Weißenberger and Angelkort 2011), not much is known on how controllers, as preparers of accounting information, relate to this shift. As the majority of controllers in Germanspeaking countries have received an accounting education nested in an environment where a separate MAS design had been widely used, they still might have reservations about an integrated MAS design, being subject to "functional fixation" (Ijiri, Jaedicke, and Knight 1966: 198). Henceforth, there might exist a so-called preparer-user perception gap between controllers - as preparers of management accounting information - and managers - as users of management accounting information. More specifically, such a preparer-user perception gap would basically consist of controllers judging the effectiveness of their tasks differently in relation to the level of integration within the MAS design compared to managers.

\subsection{Preparer-user perception gap}

Within literature, (potential) discrepancies between the perspectives of preparers and users of management information systems have been the subject of several studies. 
First of all, the user dimension has been identified as being critical for the success of management information systems ("organizational validity"; Pierce and O'Dea 2003: 258). One of the first studies in this field was provided by Schultz and Slevin (1975). Based on survey data gathered within a large manufacturing company they found that managers relate the suitability of an information system mainly to its organizational performance, i.e., its ability to enhance job performance. In another survey-based case study, Robey (1979) observed that the actual use of an information system is closely associated with its perceived usefulness. Furthermore, Tait and Vessey (1988) found in their survey that the success of an information system is highly dependent on the user involvement and less on its technical design.

In management accounting literature, a seminal indepth analysis of the user perspective on MAS design was provided by Bruns and McKinnon (1993). In a field study involving twelve North American manufacturing firms, they find that "unless a management accounting system can provide information in the metric and on the timely basis that managers demand, they will develop and use other sources of information" (Bruns and McKinnon 1993: 106). They emphasized that "management accountants must concentrate on trying to understand the information managers want and use" (Bruns and McKinnon 1993: 106).

In another study, Shields (1995) also focused on the users' perspective. With respect to activity-based costing systems - one of the major MAS innovations in the 1990s - Shields found that not technical but rather behavioral and organizational variables enhance the suitability of MAS information. Additional evidence for this phenomenon is provided by Berlant, Browning, and Foster (1990: 178) who observed with respect to the introduction of activitybased costing at Hewlett Packard that the managers “...didn't believe the numbers the accounting system produced [...] When marketing, manufacturing, product design, and accounting sat down to discuss a product, we [i.e., the managers] invariably argued how to find a product's real cost". Finally, Choe (1998) found evidence in a study of 450 Korean firms that user participation increases MAS performance; this being especially the case in situations with high task uncertainty.

The preparers' perspective is also addressed throughout a series of studies which mainly deal with the topic of the controllers' roles within the company. In an analysis based on semi-structured interview within six companies Hopper (1980) found evidence that some controllers stick to the traditional role as book-keepers though managers would prefer them acting a more service-oriented role in which the emphasis "is placed on personalized and horizontal communications" (Hopper 1980: 402). He attributed this gap partly to the controllers' "conservative and bureaucratic orientation fostered during their early training and work experience" (Hopper 1980: 402).

A first formal analysis using MAS design as a choice variable was provided by Demski and Feltham (1976). Later formal approaches on different views or objectives of preparers and users of management accounting information as well as on the resulting detrimental effects were also presented by Chwolka (1996) or Weißenberger (1997).

Despite the broad strands of literature on this subject, the term 'preparer-user perception gap' was later coined by Pierce and O'Dea (2003) who were among the first to combine an analysis of both viewpoints in their study. Based on a survey followed by semi-structured interviews, they identified differences in perceptions of production/sales managers and controllers on the management accounting information supplied by the controllers. Their main results are that the two groups have different notions on the usefulness of information items, the quality of accounting information and the usage of traditional vs. innovative management accounting techniques. Management accountants are found to "attach high priority to technical validity and see accounting systems primarily in terms of technical innovations" (Pierce and O'Dea 2003: 282). Therefore, the information they produce lacks user relevance or organizational validity. In contrast, the users of management accounting information require more timely, more broad-based, and more flexible information. As a consequence, Pierce and O'Dea stated that MAS quality can only be improved by a convergence of the perceptions of controllers and managers.

Based on the results of Pierce and O'Dea we expect that the observation of a preparer-user perception gap with respect to MAS integration will provide valuable insights not only with respect to the evaluation but also to the further advancement of controllership effectiveness in German firms. 


\subsection{Benchmark Model}

A first study on the user perspective of MAS integration and controllership effectiveness in German companies was provided by Weißenberger and Angelkort (2011) (W/A). In order to incorporate the technical description of the MAS design as well as the user perspective into their study, W/A employ a dyadic research design, i.e., from each company that participated in the study a controller (in most instances the head of controlling) as well as a general manager (i.e., a member of upper management like the CEO, managing director or division manager) were questioned. An overview of the variables analyzed by W/A is depicted in Figure 1.

\section{Figure 1: Benchmark Model by Weißenberger and Angelkort (2011)}

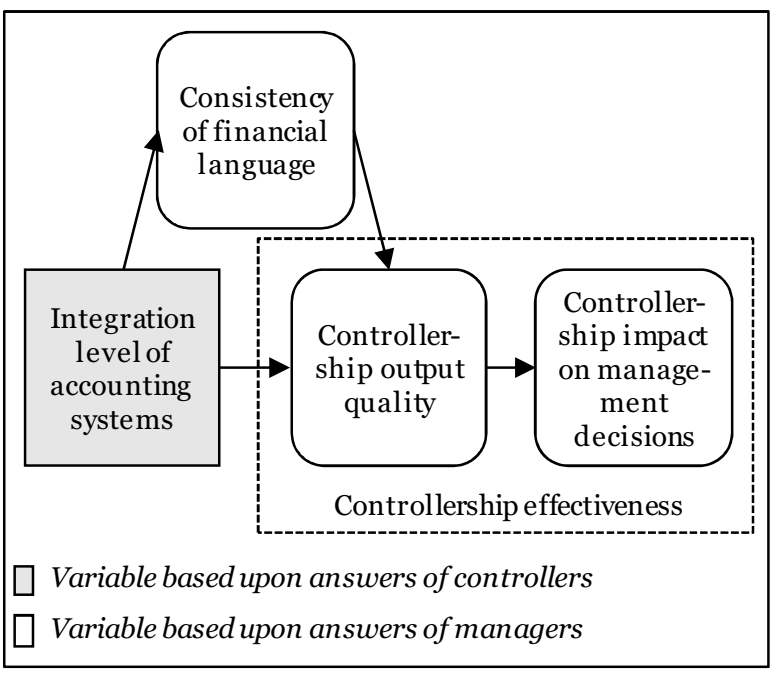

The W/A model comprises four variables: 'integration level of accounting systems', 'consistency of financial language', 'controllership output quality' and 'controllership impact on management decisions'. The latter two variables are subsumed as controllership effectiveness as only a combination of both a high output quality and a high impact contributes to fulfilling the controlling function, e.g., providing financial result controls for operating the firm's management control system.

The variable 'integration level of accounting systems' is the exogenous element of the structural model. It represents the degree to which management accounting systems are technically integrated within the financial accounting systems. The variable is measured by employing an index averaging the scores of 17 indicators which refer to controllers' tasks with respect to providing MAS information (see Appendix 1).

The three endogenous variables in the structural model reflect managers' assessments. The variable 'consistency of financial language' measures the extent to which the management perceives information, which is provided by management accounting and financial accounting as coherent. In other words, the variable represents whether management accounting and financial accounting succeed in addressing similar business phenomena in a coherent fashion. Three reflective indicators are used to form this variable (see Appendix 2). The variable 'controllership output quality' represents the management's evaluation of the controlling department's output, e.g., in terms of scope, timeliness, or accuracy. This variable is based on six reflective survey items (see Appendix 3). 'Controllership impact on management decisions' as the third endogenous variable reflects the extent to which the controllers influence the process of decision-making in management. This variable is derived from three reflective indicators (see Appendix 4).

The model tested by W/A assumes that integration level of accounting systems' has an impact on 'controllership output quality' in two distinct ways:

(1) The integration level is hypothesized to have a direct effect on the perceived controllership output quality. This rather technical viewpoint assumes that solely a more integrated accounting system design augments the output quality and thus controllership impact on management decisions by providing accounting information faster and in a more aligned fashion.

(2) Furthermore, the integration level is supposed to affect controllership output quality in an indirect way, i.e., via the mediating effect of 'consistency of financial language'. As thus integrated accounting systems are based on the data and the conceptual framework of the financial accounting system, they provide management accounting information which is coherent with financial accounting information. In other words, both financial and management accounting are assumed to supply the management with 'one version of the truth' concerning the firm's business and facilitate the establishing of a consistent financial language for internal and external communication purposes.

In this context, it has to be emphasized that the link between the integration level of accounting systems and the consistency of financial language is not as 
trivial as it may seem at first glance. While the first is a technical variable, the second is a socio-cultural variable. Looking at a consistent accounting language from a linguistic angle is more than just a technical issue (Belkaoui 1978). A consistent financial language is present when the meaning of accounting terms is equally shared by members of an organization. The meaning of a term (including an accounting term) has at least two layers: a denotation and a connotation. While denotation reflects the literal, definitional layer, connotation refers to a term's socio-cultural layer (Chandler 1997).

Connotation is as relevant as denotation to constitute a term's meaning and past accounting researchers have long since established its importance for accounting communication (e.g., Haried 1972, Hronsky, and Houghton 2001). Still, when it comes to the technical influence of an integrated MAS design on a consistent financial language, only the denotative aspect of meaning is directly affected, but not the connotative aspect. However, even a completely integrated MAS design is not a guarantee for a consistent denotation of accounting terms. As language remains a social practice shaped by the people practicing it, MAS integration is only one of many determinants for the existence of a consistent financial language within a company.

Data for the W/A study were obtained by means of a questionnaire-based survey in the period from September to November 2007. Starting point for this survey was a database including information about German Top-1,500 companies with regard to sales volume. Financial institutions were excluded due to their specific accounting requirements; other companies had to be excluded for other reasons, e.g., lack of controlling department. In the end W/A contacted 1,269 companies and acquired 149 dyadic sets of completed questionnaires, which equals a return rate of $11.7 \%$. Summary statistics on the W/A sample can be found in the appendices $5-8$.

The results of the model based on this data are shown in Figure 2. As can be seen, W/A find no evidence for a significant direct effect of the integration level of accounting systems on controllership output quality. However, the parameter estimates point towards an indirect positive effect between these two variables with 'consistency of financial language' acting as a fully mediating variable: The variable 'integration level of accounting systems' has a significant $(\mathrm{p}<.001)$ and also relevant $(.43)$ positive association with 'consistency of financial language', explaining $18 \%$ of the variance of the latter variable. The variable 'controllership output quality' is also positively associated with 'consistency of financial language' (.67; $\mathrm{p}<.001)$, with $45 \%$ of the variance of the former variable explained.

Thus, the main finding of W/A can be summed up as follows: Managers relate effective or 'good' controllership not on instrumental MAS features, but rather on the MAS's ability to provide a coherent and consistent view on the firm's business compared to the corresponding financial statements.

\section{Research design and hypothesis development}

To explore a potential preparer-user perception gap in the context of MAS integration we extend the model of W/A to include the viewpoint of controllers. More specifically, we compare the benchmark

Figure 2: Results of the SEM by Weißenberger and Angelkort (2011)

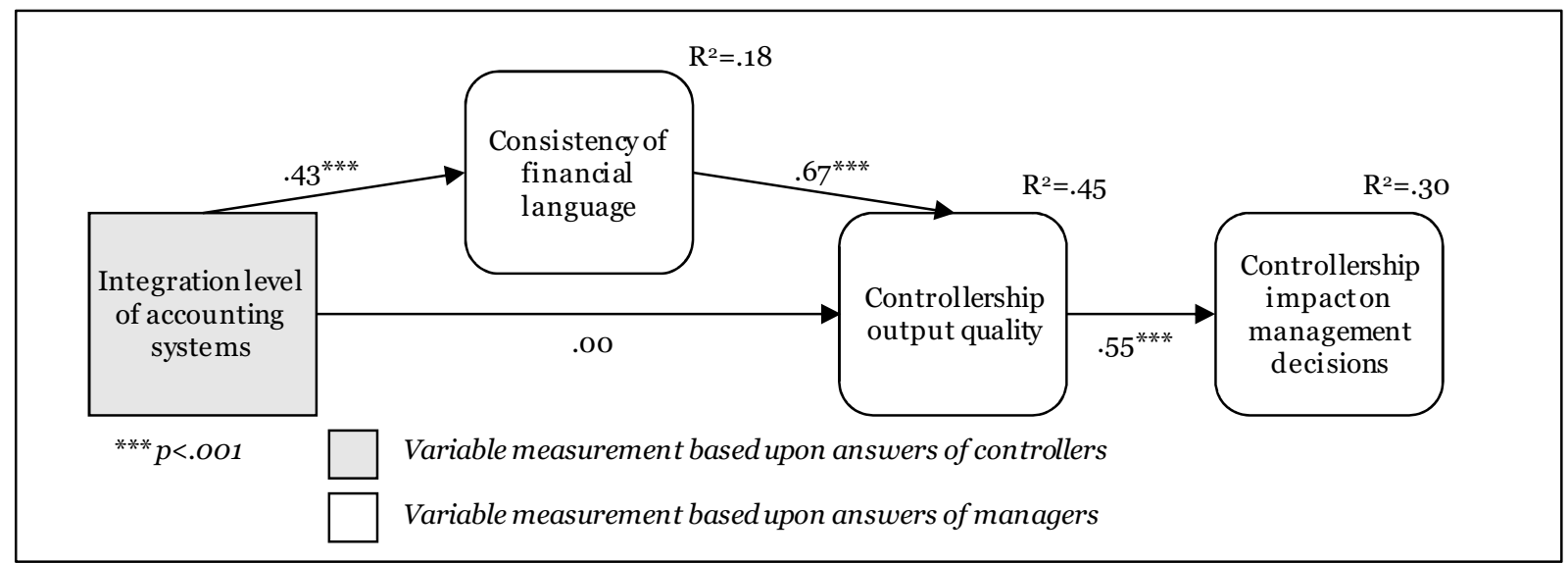


model described above (in the following denoted as 'manager model'/group 1) with a similar model (in the following denoted as 'controller model'/group 2) which is based solely on the answers of the controllers surveyed in the W/A study. The necessary data have been collected by W/A in their original study but have not yet been used for additional analyses. Overall, we use the data of 149 completed questionnaires from each group, which makes 298 completed questionnaires overall. Within this multi-group model, a preparer-user perception gap will become visible if the measured effects differ significantly between the group of the managers (group 1) and the group of the controllers (group 2).

First of all, the literature suggests that controllers as preparers of management accounting information are likely to focus on the technical validity of MAS design (Pierce and O'Dea 2003). From such a viewpoint, an integrated MAS design is deemed to be disadvantageous, as it is based on financial accounting data and, therefore, strongly dependent on external GAAP. As a consequence, an integrated MAS is not independent and flexible enough to serve all different types of managerial information demand (Jones and Luther 2005). Thus, irrespective of any socio-organizational consequences and regarding only its technical side, MAS integration is likely to have a negative effect on controllership effectiveness from the controllers' point of view. This reasoning can also be related to controllers' roles, which have been a highly discussed topic within management accounting literature (for an overview see, e.g., Sathe 1982; Granlund and Lukka 1998; and Järvenpää 2007). In order to reduce the inherent role conflict between acting as 'company watchdogs' or as 'business advisors', controllers are likely to favor an independent accounting system, which gives them the flexibility to balance their dual roles by providing information for different purposes (Indjejikian and Matějka 2006; Maas and Matějka 2009). We therefore expect controllers to associate the integration of MAS design negatively with controllership effectiveness. This leads to our first hypothesis:

H1: In contrast to the group of the managers, the direct effect of the integration level of accounting systems on controllership output quality is negative for the group of the controllers.

However, in spite of their reservations about an integrated MAS design, the literature also indicates that controllers might be empathetic towards the issue of organizational validity, i.e., considering managements' points of view regarding the suitability of management accounting information for decision-making and control purposes, as the role of controllers gradually seems to shift from being a mere "cost recorder" (Pierce and O’Dea 2003: 259) towards being a "business partner" to management (Järvenpää 2007: 99). Evidence of this role change was found by various researchers (e.g., Siegel and Sorensen 1999; Granlund and Lukka 1998; Davis and MacLaughlin 2009). Being business partners, controllers should be able to realize the relevance of providing 'one version of the truth', i.e., a consistent financial language.

Still, it is not clear whether controllers perceive a consistent financial language as important as the managers in relation to controllership output quality. After all, controllers are specialized agents whose work is embedded within an internal perspective and who are mainly providers of management accounting information (Joseph, Turley, Burns, Lewis, Scapens, and Southworth, 1996). Managers, on the other hand, as potential users of this information are also exposed to a multitude of perspectives when it comes to decision-making (Daft and Wiginton 1979). For example, they encounter external as well as internal, quantitative as well as qualitative and formal as well as non-formal information. Therefore, managers are prone to face so-called cognitive dissonances (Festinger 1957), when confronted with inconsistent or contradictory external and internal financial information. These psychologically uncomfortable states occur when sets of information (be it for inconsistency or contradiction) do not fit together and are likely to be diminished by the decisionmakers by blinding out inconsistent or contradictionary information. Consequently, we suppose that controllers relate an integrated MAS design to a consistent financial language and in effect to a higher level of controllership effectiveness, but not to the same extent as the managers do. Summing up, our second hypothesis is as follows:

H2: For the group of the controllers the extent of the indirect effect of the integration level of accounting systems on controllership output quality, with consistency of financial language acting as a mediating variable, is lower than for the group of the managers. 


\section{4. $\quad$ Research Method}

We use the data collected by W/A as the basis for our multi-group analysis and consistently employ a SEM analysis using Maximum Likelihood (ML) with the software package AMOS 18 (Byrne 2009). A multi-group analysis is an instrument to test two or more groups for equality of estimated parameters (Steenkamp and Baumgartner 1998). The procedure involves testing a series of nested models (Bagozzi and Yi 1988; Steinmetz, Schmidt, Tina-Booh, Wieczorek, and Schwartz 2009). Each model consists of a set of sub-models (one for each group to be tested) and the parameters for the set of sub-model are calculated simultaneously. In the series of tests certain sets of parameters are constrained to be equal across the sub-models and the results of these constraints on the overall model fit are assessed.

The constraints gradually become stricter as more and more sets of parameters are constrained to be equal across the groups. Since each model has tighter constraints than its antecessor, deterioration in the model fit is the usual result. The change in model fit for each step in the series of nested models is assessed using a $\chi^{2}$-difference test. Constraining the model parameters to be equal across the groups usually leads to a higher value for $\chi^{2}$ indicating a decline in model fit. However, with each constraint the model gains one degree of freedom. Therefore, the deterioration in model fit due to the constraints in place is assessed by comparing the increase of $\chi^{2}$ to the degrees of freedom gained. If the deterioration of model fit is significant, this indicates that the last parameters constrained to be equal are probably not equal between the groups.

The testing procedure usually starts with an unconstrained baseline model in which all parameters are free to vary between the groups. This is done to test for configural invariance, i.e., to assess whether the same model structure holds true for the groups. Only if this test shows acceptable values of model fit, can the parameters of the groups be compared to each other. A second test is then conducted to test for metric invariance, i.e., to check if factor loadings can be considered equal among the groups. Metric invariance is a necessary prerequisite to conduct further quantitative analysis of the multi-group model, as a means or structural relations across groups can only be legitimately compared if the underlying measurement structures are equivalent (Ployhart and Oswald 2004). Otherwise, observed differences in means or structural relations might stem from fundamental discrepancies of the underlying measurement structure distorting the comparison. However, if metric invariance cannot be established in full, it is possible to test for partial metric invariance as a minimum requirement. Partial metric invariance demands at least two items per factor to have identical factor loadings across the groups (Steenkamp and Baumgartner 1998).

On the basis of a model with at least partial metric invariance, the effects between the variables can be tested for invariance between the groups. That is, the constraints of the prior model remain in place (identical factor loading across the groups) and the specific effect is constrained to be equal across the groups. If this leads to a significant deterioration in model fit, it is highly probable that the constrained effect is not equal across the groups. If the change in the model fit shows significant differences between the effects, the different magnitudes of these unstandardized effects can be analyzed by using the results of the prior model with metric invariance.

As the group classification of a multi-group analysis must be conducted in accordance to the variable presumed to have a moderating influence on the model parameters, in our case we divide the respondents into two groups according to their function in their respective company. One group is comprised only of managers (group 1), while the other group contains controllers (group 2).

\section{Results}

\subsection{Reliability and validity of data}

Before testing for group differences concerning the effects between the variables, the reliability and validity of the latent variables for each of the two groups have to be assessed. Reliability addresses the internal consistency of a scale and is a necessary prerequisite for measurement validity, which refers to the conceptual accuracy of a scale (Schäffer 2007).

Both criteria can only be applied to reflective measurement (Bagozzi 1994), but are not feasible with a quasi-formative measurement approach as used by W/A with the exogenous variable integration level of accounting systems.

Thus, only the three endogenous variables which have been subject to reflective measurement are tested for reliability and validity within both the group of managers (group 1) and the group of 
Table 1: Reliability and validity of the endogenous variables

\begin{tabular}{lllll} 
Variable & Group & CA & FR & AVE \\
\hline Consistency of financial language & 1 & .82 & .83 & .62 \\
\cline { 2 - 5 } & 2 & .79 & .81 & .59 \\
\hline Controllership output quality & 1 & .90 & .88 & .60 \\
\hline $\begin{array}{l}\text { Controllership input on management } \\
\text { decisions }\end{array}$ & 2 & .82 & .83 & .50 \\
\hline CA Cronbach's Alpha; FR = Factor Reliability; & $\mathbf{1}$ & .89 & .89 & .73 \\
\hline
\end{tabular}

Table 2: Discriminant validity according to the Fornell-Larcker criterion

\begin{tabular}{lllllll} 
Variable & AVE & & \multicolumn{4}{l}{ Squared correlation with variable } \\
\cline { 3 - 7 } & & & $\begin{array}{l}\text { Consistency of } \\
\text { financial language }\end{array}$ & $\begin{array}{l}\text { Controllership output } \\
\text { quality }\end{array}$ \\
\hline Group & $\mathbf{1}$ & $\mathbf{2}$ & $\mathbf{1}$ & $\mathbf{2}$ & $\mathbf{1}$ & $\mathbf{2}$ \\
\hline Consistency of financial language & .62 & .59 & - & - & - & - \\
\hline Controllership output quality & .60 & .50 & .45 & .43 & & .32 \\
\hline Controllership input on management decisions & .73 & .69 & .09 & .09 & .31 & .32
\end{tabular}

Table 3: Goodness-of-fit indices for confirmatory factor analysis

\begin{tabular}{|c|c|c|c|c|}
\hline Index & Group 1 & Group 2 & Critical Value & References \\
\hline$\overline{\chi^{2} / \mathrm{df}}$ & 1.00 & 1.21 & $\leq 2.0$ & Byrne (1989: 55) \\
\hline p-value & .47 & .17 & $\geq .05$ & Bagozzi and Yi (1988: 77) \\
\hline RMSEA & .002 & .038 & $\leq .05$ & Browne and Cudeck (1993: 144) \\
\hline GFI & .95 & .94 & $\geq .90$ & Schermelleh-Engel et al. (2003: 43) \\
\hline AGFI & .92 & .91 & $\geq .90$ & Bagozzi and Yi (1988: 77) \\
\hline$\overline{\mathrm{CFI}}$ & 1.00 & .99 & $\geq .97$ & Schermelleh-Engel et al. (2003: 42) \\
\hline TLI & 1.00 & .98 & $\geq .97$ & Schermelleh-Engel et al. (2003: 41) \\
\hline
\end{tabular}

controllers (group 2). As presented in Table 1, all three endogenous variables fulfill the common criteria for reliability and validity (descriptive data on the endogenous variables are presented in Appendix 2-4). The values for Cronbach's alpha (CA) as the most common measure of reliability exceed the critical value of .70 (Nunnally and Bernstein 1994). However, as Cronbach's alpha has the shortcoming of being positively related to the number of items, the factor reliability (FR) and the average variance extracted (AVE) also have to be taken into consideration. As can be seen, all values for factor reliability (FR) are above the critical value of .6o and all values for average variance extracted (AVE) exceed the threshold of .50 (Bagozzi and Yi 1988).

The Fornell-Larcker criterion (Fornell and Larcker 1981), as an index for discriminant validity, i.e., the degree to which indicators underlying one latent variable vary independently from those underlying another latent variable is also fulfilled by every endogenous variable. In other words, the average variance explained by each variable exceeds the squared correlation between the variable and the other variables. The details are depicted in Table 2 below.

With respect to the measurement quasi-formative variable 'integration level of accounting systems', 
W/A have been following suggestions by Bollen and Lennox (1991), using a summary index on 17 indicators reflecting comprehensively the five key controller tasks advocated in literature (Weber and Schäffer 2008). In line with other empirical studies that also measure the level of accounting integration in German-speaking countries on the basis of surveys (e.g., Müller 2006), W/A also find a broad variance with respect to MAS integration, as well as evidence that numerous firms have already implemented an integrated MAS design. Moreover, the items underlying the index used by W/A are in line with the relevant literature on MAS integration. Descriptive data on the accounting integration index can be found in Appendix 1.

With respect to overall model fit, Table 3 shows the goodness-of-fit indices of the confirmatory factor analysis for both groups. The ratio of chi-square $\left(x^{2}\right)$ and the degrees of freedom $\left(\chi^{2} / \mathrm{df}\right)$ relates to the null hypothesis postulating that specification of the factor loadings, factor variances, covariances, and error variances are valid (Bollen 1989: 265-268). The probability value (p-value) associated to $\chi^{2} / \mathrm{df}$ is higher the closer the fit between the hypothesized model and the perfect fit is. The root mean square error of approximation (RMSEA) is an index which takes into account the error of approximation in the population and compares it to optimally chosen parameter values (Browne and Cudek 1993). The goodness-of-fit index (GFI) and the adjusted goodness-of-fit index (AGFI) are absolute indices of fit as they both compare the hypothesized model with no model at all by measuring the explained amount of variance and covariance in the data $\mathrm{CHu}$ and Bentler 1995). The comparative fit index (CFI) and the Tucker-Lewis index (TLI) are incremental measures of fit as they compare the hypothesized model to a so-called null model, which allows all the variables in the model to have variation but no correlation (Byrne 2009). As can be seen, all indices are above or respectively below their critical thresholds. Therefore, the models for both groups fit the empirical data very well.

Finally, we conducted Harman's (1967) single-factor test for possible signals of a common method bias. The tests for both groups did not find evidence for the existence of a common factor underlying all survey items.

\subsection{Multi-group SEM}

Our aim is to find out whether for the respondents, being either part of the controllers or managers as organizational groups, the group membership has a moderating effect upon the effects of the benchmark model. In other words, we intend to detect whether the group of controllers and the group of managers make different associations with the variables surveyed. We focus on possible different perceptions on

\section{Figure 3: Multi-group analysis}

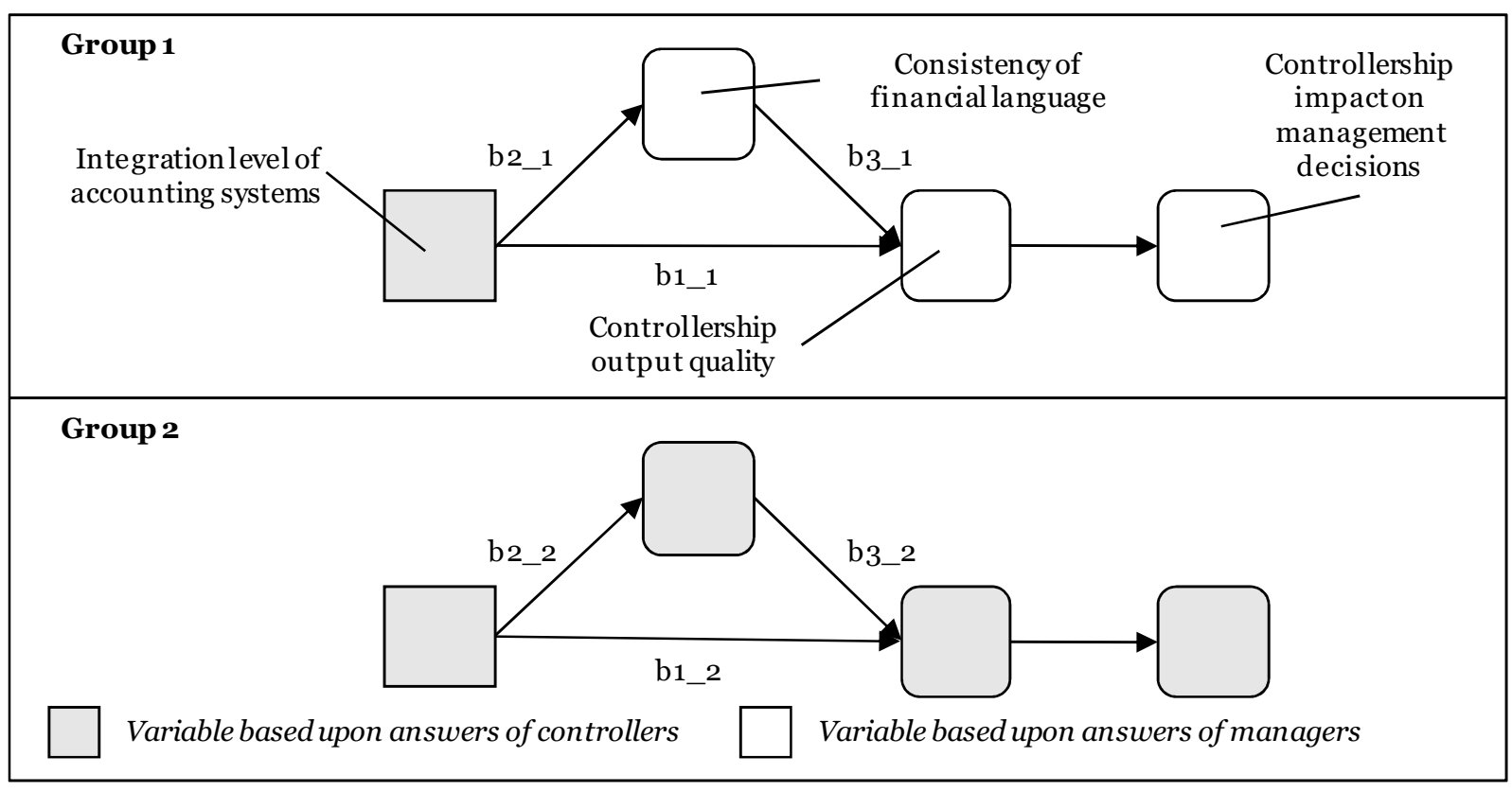


how the 'integration level of accounting systems' influences the "controllership output quality'.

In this setting, 'integration level of accounting systems' is describing the technical MAS setting, in which either managers or controllers judge the respectively perceived levels of 'consistency of financial language', 'controllership output quality' and 'controllership impact on management decisions'. Our subsequent statistical analysis does not focus on the absolute values of these variables, but rather on the covariances between these variables which reflect the causal relationships expressed by our hypotheses 1 and 2.

If any differences regarding the direct effect (hypothesis 1) and/or the indirect effect (hypothesis 2) are observed, this points towards differing associations between the respective variables and thus also differing causal relations from the managers' vs. controllers point of view on what constitutes effective controllership (user-preparer perception gap).

To reflect the perspective of the managers as the first group all endogenous variables are surveyed with the managers while only the exogenous variable 'integration level of accounting systems' is based on the controllers' answers. This sub-model has the same layout as the benchmark model by W/A. To catch the perception of the controllers as the second group we use the same model structure, but this time all variables, the exogenous as well as all the endogenous ones, are based upon the answers of the controllers. Thus, in the second group, issues, e.g., like "controllers play a very important role in the decision-making process of our organization" (item 1 in variable "controllership impact on management decisions, see appendix 4) reflect the controllers' assessment of this issue. A schema of our approach is depicted in Figure 3.

We test for significant differences concerning the direct (b1_1 and b1_2) and the indirect effect (b2_1 - b3_1 and b2_2 $\cdot$ b3_2) between the variable integration level of accounting systems' and 'controllership output quality' across the two groups in four steps:

(A) In a first step, we test the model for configural invariance. This is conducted by testing the unconstrained model A in which all parameters of the first and second group (e.g., factor loadings) are estimated freely, i.e., only the model structure is constrained to be the same among the groups. As depicted in Table 4, the measures of fit of the unconstrained model A indicate that the same model structure holds true for both groups. The basis for a multi-group comparison is therefore established.

(B) In a second step, we test for full metric invariance by constraining all factor loadings to be equal across both groups. Though these constraints lead to an increase of $\chi^{2}$ by 15.44, the decline in model fit is not significant since 8 degrees of freedom are gained. Thus, full metric invariance can be assumed and we can legitimately compare the direct and indirect effect between the two groups.

(C) We subsequently constrain the direct effect between the variable integration level of accounting systems' and 'controllership output quality' to be the equal across the two groups. In other words, we force the effect b1_1 to be identical to b1_2. All prior constraints remain in place. Table 4 shows that equalizing the direct effect leads to a slight deterioration of model fit with $\chi^{2}$ increasing by $.41 \mathrm{com}$ pared to the model B. This deterioration of model fit is far below the threshold of 3.84 (for 1 degree of freedom gained). Therefore, our first hypothesis of

\section{Table 4: Results of multi-group analysis}

\begin{tabular}{|c|c|c|c|c|c|}
\hline Model & Compared Model & $\chi^{2}(\mathrm{df})$ & $\Delta \chi^{2}(\Delta \mathrm{df})$ & RMSEA & CFI \\
\hline A: Configural invariance & - & $\begin{array}{l}117.33 \\
(102)\end{array}$ & - & .023 & .991 \\
\hline B: Full metric invariance & $\mathrm{A}$ & $\begin{array}{l}132.77 \\
(110)\end{array}$ & $\begin{array}{l}15 \cdot 44 \\
(8)\end{array}$ & .026 & .986 \\
\hline C: Invariance of direct effect & B & $\begin{array}{l}133.18 \\
(111)\end{array}$ & $\begin{array}{l}.41 \\
(1)\end{array}$ & .026 & .987 \\
\hline D: Invariance of indirect effect & $\mathrm{B}$ & $\begin{array}{l}141.03 \\
(112)\end{array}$ & $\begin{array}{l}8.25^{*} \\
(2)\end{array}$ & .030 & .983 \\
\hline
\end{tabular}

$\chi^{2}=$ chi-square $d f=$ degrees of freedom; RMSEA = root mean square error of approximation; $C F I=$ comparative fit index 
different direct effects between the two groups is not corroborated.

(D) Finally, we test the invariance of the indirect effect between the two groups. Put plainly, we set the effect b2_1 equal to b2_2 and the effect b3_1 equal to b3_2. In contrast to step (C), these constraints lead to a significant deterioration of the model fit with a $\chi^{2}$-difference of 8.25 compared to the model B (although 2 degrees of freedom are gained). The null hypothesis of an equal indirect effect among the two groups has, therefore, to be rejected and it can be assumed that group membership has a moderating effect on the indirect link between the variables 'integration of accounting systems' and 'controllership output quality'.
To assess the difference in the indirect effect between the two groups more explicitly we have to consider the outcome of model $B$ with full metric invariance. As can be seen in Figure 4, all effects, except the direct effects b1_1 and b1_2, are highly significant at the .001 level. Furthermore, both effects constituting the indirect effect are greater for the group of the managers than for the group of the controllers.

Especially the magnitude of the effect between the variable 'consistency of financial language' and 'controllership output quality' is twice the size in the group of the managers (.69) than in the group of the controllers (.31). While the difference of the effects b2_1 (.59) and b2_2 (.56) is not as distinctive, the

\section{Figure 4: Empirical results of model B with full metric invariance}

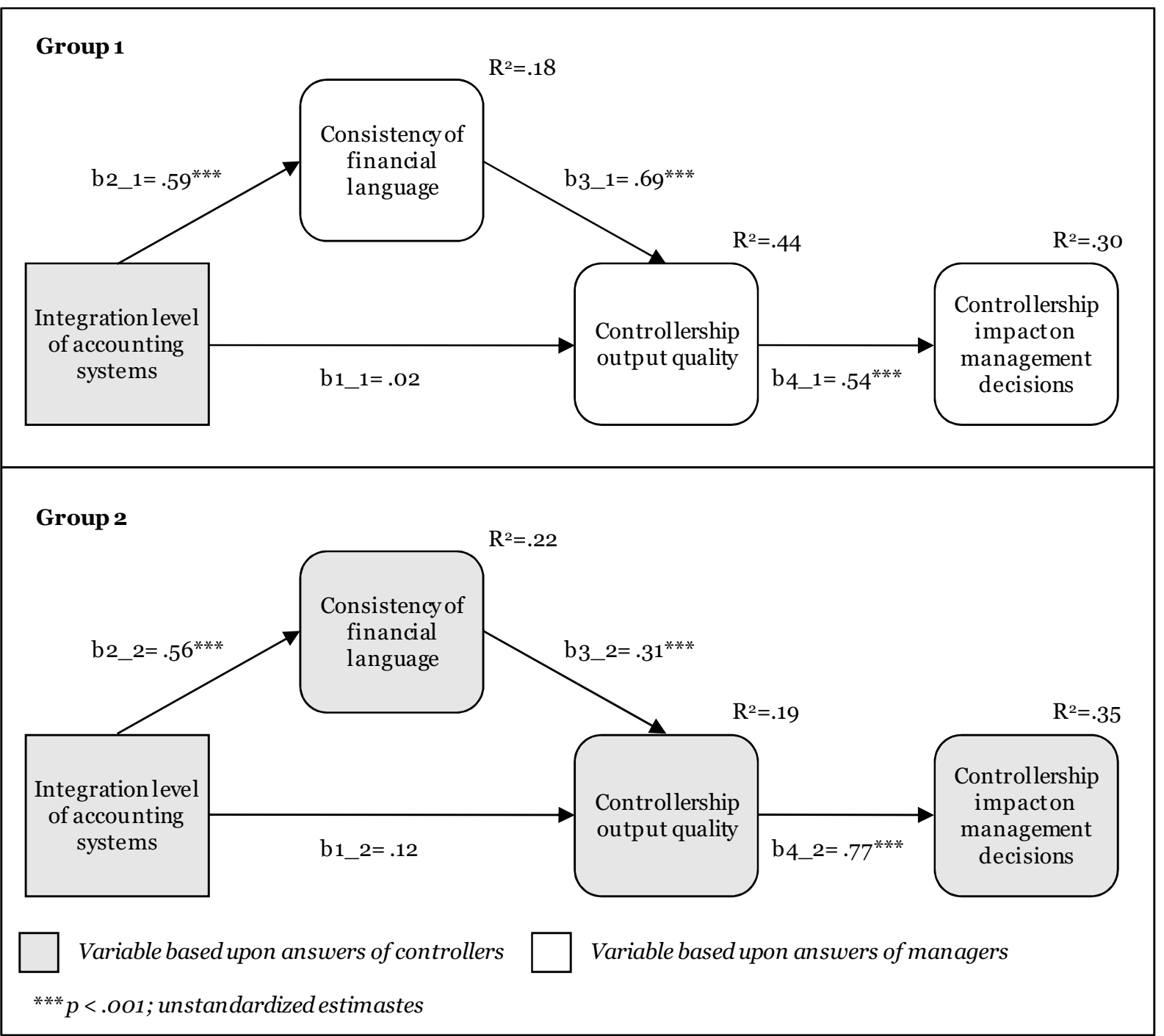


overall magnitude of the indirect effect is .41 for the group of the managers and .17 for the group of the controllers (calculated by multiplying the respective path coefficients b2 and b3).

This finding corroborates the second hypothesis giving evidence that the indirect effect between the variables 'integration level of accounting systems' and 'controllership output quality' is higher for the group of managers than for the group of controllers. What is noteworthy is the fact that the direct effect between the 'integration level of accounting systems' and the 'controllership output quality' is neither negative nor significant for the group of the controllers. Therefore, there is no evidence suggesting that controllers believe in the superiority of a separate MAS as an intermediate basis for managerial decision-making and control purposes. A potential explanation for this is that controllers are by now aware of the shift towards an integrated MAS and have accepted it as new common practice. They might even expect their impact on managerial decision-making to increase with a consistent financial language and the associated higher controllership output quality.

It is also remarkable that while the effect between the 'integration level of accounting systems' and the 'consistency of financial language' seems to be equally strong among both groups, the effect between the latter and the "controllership output quality' is far higher for the group of the managers than for the group of the controllers. Indeed, the difference of the indirect effect appears to be mainly caused by this link. A possible explanation of these findings might be that although both groups realize that an integration of accounting systems is paramount to establishing a consistent financial language in the company, controllers estimate its impact - i.e., the idea of 'one version of the truth' on the perceived controllership output quality fairly low in comparison to the managers.

\section{Discussion and conclusion}

Relating our findings to prior literature, the differing associations between the variables 'integration level of accounting systems', 'consistency of financial language' and 'controllership output quality' resulting in a significantly stronger indirect (or mediated) effect for the managers compared to the controllers indicate a potential preparer-user perception gap with respect to MAS integration and controllership effectiveness.
Our results can be explained by the notion that managers perceive management accounting information provided by controllers as of high quality if it is in line with the financial GAAP perspective on the firm's business. Following this line of argument, the existence of a consistent financial language would then be of high importance to managers when assessing controllership output quality and deciding on its use. Controllers, on the other hand, even though they may be aware of a consistent financial language being a driver for controllership effectiveness, might associate a lower impact of this variable. The low $\mathrm{R}$ square value of 'controllership output quality' in the group of controllers $\left(\mathrm{R}^{2}=.19\right)$ compared to the group of managers $\left(\mathrm{R}^{2}=.44\right)$ also indicates that according to controllers' perception there must be other drivers of controllership effectiveness that have not been captured in our study.

Still, it must be noted that our results do not indicate whether controllers are aware of the potentially differing perceptions or whether they are ignorant regarding these differences. Controllers' awareness of this perception gap is of relevance regarding the possible consequences on the relationship between controllers and managers.

In the case that controllers fail to notice the perception gap, they may achieve a high technical validity with respect to the MAS design, but due to their ignorance regarding managers' perceptions possibly only a low organizational validity, i.e., a MAS design which is from the managers' point of view not sufficiently suitable for decision-making and control purposes, thus leading to frictions, e.g., discontentment or even disuse of management accounting information.

In the case that controllers are aware of the managers' differing perceptions, a potency for these frictions remains as controllers might still have the opinion that their way of providing management accounting information is superior from a normative point of view, thus not acquiescing to providing managers' with 'good' management accounting information from the managers' point of view. Such a reasoning would also be in line with the major body of management accounting textbooks which from an instrumental perspective mainly deal with MAS design issues in a decision-theory setting (i.e., discussing what type of accounting information is needed to resolve a given decision-making problem), see, e.g., Weygandt, Kieso, and Kimmel (2005). 
Furthermore, controllers could try to convince managers' of the advantages of a separate MAS design, which relates less to 'consistency of financial language' but rather to other antecedents driving 'controllership output quality' from the controllers' point of view.

Finally, even if controllers try to provide 'good' management accounting information from the managers' point of view, a perception gap indicates different types of "Weltanschauung" (Belkaoui 1978: 97), thus reducing the potential for the empathy that is needed to successfully achieve organizational validity. As the way certain artifacts or concepts are perceived has an undeniable impact on human cognition and behavior (see, for example, the 'label effect' described by Jain 1973), even the sheer existence of different perceptions are highly likely to cause frictions between controllers and managers regarding the design (and use) of MAS.

Thus, independent of whether or not controllers are aware of the perception gap, this gap could be diminished by gaining a better understanding on how management accounting information is used outside an instrumental context. As Pierce and O'Dea pointed out, "improved management accounting information can only come about through a convergence of the perceptions of management accountants and managers..." (Pierce and O'Dea 2003: 287).

Such a convergence would be beneficial for both groups: Managers could profit, since the quality of management accounting information they perceive as necessary for the process of decision-making would be augmented. Controllers could also benefit, since the perception gap dilutes their influence on managerial decision-making. By supplying information that is in line with the demand of management not only with respect to technical validity, but also with organizational validity, they could strengthen their role as business advisors and thus gain a more influential position inside the organization.

A possible mitigation of the different perceptions between managers and controllers could be achieved by enhancing the communication between the two groups. Managers, on the one hand, could clarify what type of information they use and need. Controllers, on the other hand, might want to dissociate themselves from being specialists and embrace a broader and hence a more conceptual view on the organization.

Our study is subject to some limitations.

Firstly, our analysis is based on data gathered from companies' top management/top controller level. It is probable that the viewpoint on the effects of an integrated MAS design is not only dependent on the specific functional group of the respondent (on whether he or she belongs to the group of the managers or the controllers), but also on the hierarchy level of the respondent. In other words, it remains unclear whether a preparer-user perception gap concerning the MAS design also exists at lower levels of the hierarchy.

Secondly, the findings are limited due to the nonrandom sampling of the firms. The underlying population comprises 1,269 of the biggest companies in Germany by sales volume and, therefore, the results may not apply to smaller firms. Furthermore, as we rely on cross-sectional data, the findings might differ when regarding a specific industry. In addition to that, the possibility of a sample selection bias exists. It cannot be ruled out that companies voluntarily returning the questionnaire differ in relevant aspects from the overall population.

Thirdly, the variable 'integration level of accounting system' is an index and using this composite assumes that it completely captures the whole construct. The underlying items were created in line with relevant literature but it is possible that some aspects might remain unconsidered. However, the overall procedure is still regarded as legitimate for research practice (Diamantopoulos 2006).

Fourthly, the variable 'integration level of accounting systems' relies on the answers of the controllers throughout the whole multi-group analysis. Though controllers can be considered as adequate informants regarding this particular variable, the possibility exists that the multi-group analysis results in a different outcome if the variable was measured on basis of the managers' answers.

Despite these limitations, our findings implicate the importance of the socio-organizational system perspective for future research. The quality and the mechanisms of an accounting system are not to be seen as independent from the functional and hierarchical perspective of the evaluator.

To catch the full organizational perspective on an existing accounting system one has to analyze the distinct perspectives of all groups involved (Kumar, 
Stern, and Anderson 1993). Although this is a rather complex and laborious research procedure, it offers the chance to construct a holistic image of perceived realities. Since there is no unbiased and objective reality, the notion that it could be distorted by focus- ing on a distinct informant has to be reassessed. By accepting and analyzing subjectivity we can learn more about social reality which consists of a multiplicity of different perspectives.

\section{Appendix}

\section{Appendix 1: Summary statistics on the 17 indicators underlying the variable 'integration level of accounting systems' divided into five sub-indices referring to the main tasks constituting controllership}

\section{Indicator}

Mean

Std. Dev.

\begin{tabular}{|c|c|c|}
\hline \multicolumn{3}{|l|}{ Sub-index: Planning and budgeting } \\
\hline $\begin{array}{l}\text { To which extent is short-term planning and budgeting based on valuation methods in accordance with } \\
\text { financial GAAP on top management level? } \\
\qquad(\mathrm{O}=\text { very low, ..., } 5 \text { = very high } / \mathrm{N}=149)\end{array}$ & 4.08 & 1.21 \\
\hline $\begin{array}{l}\text { To which extent is valuation within medium-term planning and budgeting based on valuation methods } \\
\text { in accordance with financial GAAP on top management level? } \\
\qquad(\mathrm{O}=\text { very low, ..., } 5 \text { = very high } / \mathrm{N}=147)\end{array}$ & 4.05 & 1.22 \\
\hline $\begin{array}{l}\text { What is the level of congruence between management control structure and legal structure for planning } \\
\text { and budgeting purposes? } \\
\qquad(\mathrm{O}=\text { very low, } \ldots, 5=\text { very high } / \mathrm{N}=149)\end{array}$ & $3 \cdot 34$ & 1.44 \\
\hline \multicolumn{3}{|l|}{ Sub-index: Reporting } \\
\hline $\begin{array}{l}\text { To which extent are deadlines for management reporting and financial reporting harmonized? } \\
\qquad(\mathrm{o}=\text { very low, } \ldots, 5=\text { very high } / \mathrm{N}=149)\end{array}$ & 4.28 & 1.03 \\
\hline $\begin{array}{l}\text { How many workdays are required to report monthly financial key performance indicators (KPI) to top } \\
\text { management in accordance to financial GAAP? } \\
\qquad \begin{array}{l}(0=\text { KPIs are not calculated in accordance with financial GAAP } \\
1=>20 \text { workdays } \\
2=13-20 \text { workdays } \\
3=7-12 \text { workdays } \\
4=4-6 \text { workdays } \\
5=1-3 \text { workdays } / \mathrm{N}=149)\end{array}\end{array}$ & 2.91 & 1.33 \\
\hline $\begin{array}{l}\text { To which extent are imputed or opportunity cost and revenue types used for management control pur- } \\
\text { poses? (reverse coded item) } \\
\qquad(\mathrm{o}=\text { very high, } \ldots, 5 \text { = very low } / \mathrm{N}=149)\end{array}$ & 3.62 & 1.51 \\
\hline $\begin{array}{l}\text { To which extent can single line items/sums in the internal management reports be reconciled with } \\
\text { corresponding items in the income statement? } \\
\qquad(\mathrm{O}=\text { very high, } \ldots, 5=\text { very low } / \mathrm{N}=149)\end{array}$ & 3.86 & 1.31 \\
\hline $\begin{array}{l}\text { To which extent is the internal measure for operating income in accordance with the operating income } \\
\text { published in the financial statements? } \\
\qquad(\mathrm{O}=\text { very low, } \ldots, 5=\text { very high } / \mathrm{N}=149)\end{array}$ & 4.20 & 1.06 \\
\hline
\end{tabular}

How many adjustments are necessary for reconciling the operating income based on financial GAAP to the financial KPI used for internal management control purposes? (reverse coded item)

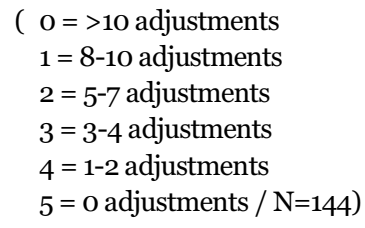


Appendix 1 continued: Summary statistics on the 17 indicators underlying the variable integration level of accounting systems' divided into five sub-indices referring to the main tasks constituting controllership

Indicator

Mean

Std. Dev.

Sub-index: Reporting

To which extent differs the operating income based on financial GAAP in volume from the financial KPI

used for internal management control purposes? (reverse coded item)

$(\mathrm{o}=$ very high,,.., 5 = very low $/ \mathrm{N}=146)$

Sub-index: Performance measurement

To which extent is overall top management compensation based on financial GAAP based profit measures?

$$
(\mathrm{o}=\text { very low, } \ldots, 5=\text { very high } / \mathrm{N}=148)
$$

Sub-index: Accounting information technology design

In our company, only one set of accounts (books) is used for both financial and management accounting purposes.

$$
(0 \text { = definitely false, } \ldots, 5=\text { definitely true } / \mathrm{N}=149)
$$

In our company there are one or more company-wide accounting databases containing actual and planning data that are used for both financial and management accounting purposes.

$$
\text { ( } 0 \text { = definitely false, ..., } 5 \text { = definitely true } / \mathrm{N}=149 \text { ) }
$$

$3.83 \quad 1.55$

In our company, an integrated IT system (e.g., SAP-SEM) is available that provides a basis for both

internal management reporting and consolidated financial statements.

Sub-index: Administration of the controlling function

In our company, management accountants and financial accountants report to the same member of the executive board

$$
(\mathrm{O}=\text { definitely false, } \ldots, 5=\text { definitely true } / \mathrm{N}=149)
$$

In our company, there is a mutual professional exchange between controllers and financial accountants.

$$
\text { ( } \mathrm{o}=\text { definitely false, } \ldots, 5 \text { = definitely true } / \mathrm{N}=149 \text { ) }
$$

In our company, the financial accountants are briefed by controllers on management reporting issues.

$$
\text { ( } 0 \text { = definitely false, } \ldots, 5=\text { definitely true } / \mathrm{N}=149 \text { ) }
$$

\begin{tabular}{|c|c|c|c|c|}
\hline Item & Group & Mean & Std. Dev. & t-test \\
\hline \multirow{2}{*}{$\begin{array}{l}\text { Controllers and financial accountants have the same understand- } \\
\text { ing of business performance. } \\
\qquad(\mathrm{O}=\text { definitely false, } \ldots, 5=\text { definitely true } / \mathrm{N}=149)\end{array}$} & Manager & 3.78 & 1.11 & \multirow{2}{*}{$\begin{array}{l}t=0.527 \\
(p=.598)\end{array}$} \\
\hline & Controller & 3.85 & 1.01 & \\
\hline \multirow{2}{*}{$\begin{array}{l}\text { Information provided by the controllers is consistent with ac- } \\
\text { counting information based on financial GAAP. } \\
\qquad(\mathrm{O}=\text { definitely false, } \ldots, 5=\text { definitely true } / \mathrm{N}=149)\end{array}$} & Manager & 3.46 & 1.26 & \multirow{2}{*}{$\begin{array}{l}t=2.606 \\
(p=.010)\end{array}$} \\
\hline & Controller & 3.83 & 1.14 & \\
\hline \multirow{2}{*}{$\begin{array}{l}\text { Information provided by controllers and financial accountants } \\
\text { adds up to a consistent view on the firm's business. } \\
\qquad(\mathrm{O}=\text { definitely false, } \ldots, 5=\text { definitely true } / \mathrm{N}=149)\end{array}$} & Manager & 3.88 & 1.11 & \multirow{2}{*}{$\begin{array}{l}\mathrm{t}=1.935 \\
(\mathrm{p}=.054)\end{array}$} \\
\hline & Controller & 4.11 & 0.98 & \\
\hline
\end{tabular}

Appendix 2: Summary statistics on items underlying the variable 'consistency of financial language' 
Appendix 3: Summary statistics on items underlying the variable 'controllership output quality'

\begin{tabular}{|c|c|c|c|c|}
\hline Item & Group & Mean & Std. Dev. & t-test \\
\hline $\begin{array}{l}\text { The management reports cover all important fields of business } \\
\text { activity. } \\
\qquad(\mathrm{o}=\text { definitely false, } \ldots, 5 \text { = definitely true } / \mathrm{N}=149 \text { ) }\end{array}$ & $\begin{array}{l}\text { Manager } \\
\text { Controller }\end{array}$ & $\begin{array}{l}3.94 \\
4.16\end{array}$ & $\begin{array}{l}1.04 \\
0.80\end{array}$ & $\begin{array}{l}\mathrm{t}=2.074 \\
(\mathrm{p}=.039)\end{array}$ \\
\hline $\begin{array}{l}\text { The management information system provided by controllers } \\
\text { reflects actual circumstances in a comprehensive and valid fash- } \\
\text { ion. } \\
\qquad(\mathrm{o}=\text { definitely false, } \ldots, 5=\text { definitely true } / \mathrm{N}=149)\end{array}$ & $\begin{array}{l}\text { Manager } \\
\text { Controller }\end{array}$ & $\begin{array}{l}3.90 \\
4.14\end{array}$ & $\begin{array}{l}0.84 \\
0.67\end{array}$ & $\begin{array}{l}t=2.741 \\
(p=.006)\end{array}$ \\
\hline $\begin{array}{l}\text { Information provided by controllers is very precise. } \\
\qquad(0=\text { definitely false, } \ldots, 5=\text { definitely true } / \mathrm{N}=149)\end{array}$ & $\begin{array}{l}\text { Manager } \\
\text { Controller }\end{array}$ & $\begin{array}{l}3.91 \\
3.99\end{array}$ & $\begin{array}{l}0.83 \\
0.76\end{array}$ & $\begin{array}{l}\mathrm{t}=0.871 \\
(\mathrm{p}=.384)\end{array}$ \\
\hline $\begin{array}{l}\text { Information provided by controllers is up-to-date. } \\
\qquad(0=\text { definitely false }, \ldots, 5=\text { definitely true } / \mathrm{N}=149)\end{array}$ & $\begin{array}{l}\text { Manager } \\
\text { Controller }\end{array}$ & $\begin{array}{l}3.77 \\
3.96\end{array}$ & $\begin{array}{l}1.06 \\
0.79\end{array}$ & $\begin{array}{l}t=1.798 \\
(p=.073)\end{array}$ \\
\hline $\begin{array}{l}\text { Information content and explanatory power of management } \\
\text { reports are both high. } \\
\qquad(\mathrm{O}=\text { definitely false, } \ldots, 5=\text { definitely true } / \mathrm{N}=149)\end{array}$ & $\begin{array}{l}\text { Manager } \\
\text { Controller }\end{array}$ & $\begin{array}{l}3.78 \\
3.96\end{array}$ & $\begin{array}{l}0.95 \\
0.71\end{array}$ & $\begin{array}{l}t=1.861 \\
(p=.064)\end{array}$ \\
\hline
\end{tabular}

\section{Appendix 4: Summary statistics on items underlying the variable 'controllership impact on} management decisions'

\begin{tabular}{|c|c|c|c|c|}
\hline Item & Group & Mean & Std. Dev. & t-test \\
\hline \multirow{2}{*}{$\begin{array}{l}\text { Controllers play a very important role in the decision-making } \\
\text { process of our organization. } \\
\qquad(\mathrm{O}=\text { definitely false, } \ldots, 5=\text { definitely true } / \mathrm{N}=149 \text { ) }\end{array}$} & Manager & 3.84 & 0.98 & \multirow{2}{*}{$\begin{array}{l}t=0.458 \\
(p=.647)\end{array}$} \\
\hline & Controller & 3.79 & 0.84 & \\
\hline \multirow{2}{*}{$\begin{array}{l}\text { Management sets a high value on the controllers' opinion in the } \\
\text { decision-making process. } \\
\qquad(\mathrm{O}=\text { definitely false, } \ldots, 5=\text { definitely true } / \mathrm{N}=149)\end{array}$} & Manager & 3.81 & 0.91 & \multirow{2}{*}{$\begin{array}{l}\mathrm{t}=2.227 \\
(\mathrm{p}=.027)\end{array}$} \\
\hline & Controller & $3 \cdot 57$ & 0.93 & \\
\hline \multirow{2}{*}{$\begin{array}{l}\text { Controllers have a strong influence on management decisions. } \\
\qquad(\mathrm{o}=\text { definitely false, } \ldots, 5=\text { definitely true } / \mathrm{N}=149)\end{array}$} & Manager & $3 \cdot 51$ & 1.00 & \multirow{2}{*}{$\begin{array}{l}t=1.723 \\
(p=.086)\end{array}$} \\
\hline & Controller & $3 \cdot 32$ & 0.92 & \\
\hline
\end{tabular}

\section{Appendix 5: Summary statistics on company size measures of surveyed firms}

\begin{tabular}{lllllll} 
Variable & n & Mean & Std. Dev. & $\begin{array}{l}\text { Lower } \\
\text { quartile }\end{array}$ & Median & $\begin{array}{l}\text { Upper } \\
\text { quartile }\end{array}$ \\
\hline Sales (Million EUR) & 146 & 4,015 & 9,761 & 530 & 978 & 2,254 \\
\hline Total assets (Million EUR) & 126 & 4,503 & 13,834 & 350 & 795 & 2,211 \\
\hline Number of employees & 148 & 16,137 & 51,799 & 1,556 & 3,825 & 9,375 \\
\hline
\end{tabular}




\section{Appendix 6: Surveyed firms by industry}

\begin{tabular}{lll} 
Variable & Frequency & Percentage \\
\hline Chemicals/health care & 22 & $15.28 \%$ \\
\hline Industrial goods & 20 & $13.89 \%$ \\
\hline Wholesale/retail & 19 & $13.19 \%$ \\
\hline Utilities/telecommunication & 15 & $10.42 \%$ \\
\hline Automotive & 12 & $8.33 \%$ \\
\hline Consumer goods & 12 & $8.33 \%$ \\
\hline Transport/logistics & 9 & $6.25 \%$ \\
\hline Construction & 8 & $5.56 \%$ \\
\hline Media/software/technology & 5 & $3.47 \%$ \\
\hline Others & 22 & $15.28 \%$ \\
\hline $\mathrm{n}$ & 144 & \\
\hline
\end{tabular}

\section{Appendix 7: Leading GAAP as indicated by surveyed firms}

\begin{tabular}{lll} 
Variable & Frequency & Percentage \\
\hline IFRS & 77 & $52.03 \%$ \\
\hline German GAAP (HGB) & 59 & $39.86 \%$ \\
\hline US-GAAP & 12 & $8.11 \%$ \\
\hline $\mathrm{n}$ & 148 &
\end{tabular}

\section{Appendix 8: Listing status of surveyed firms}

\begin{tabular}{lll} 
Variable & Frequency & Percentage \\
\hline Not listed & 110 & $73.8 \%$ \\
\hline Listed & 39 & $26.2 \%$ \\
\hline $\mathrm{n}$ & 149 & \\
\hline
\end{tabular}

\section{Acknowledgement}

We would like to thank Nina Franzen, Bernhard Hirsch, Andreas Hoffjan, Frank Holthoff, Holger Steinmetz and the participants of the 2010 EAA conference in Istanbul, of the $2010 \mathrm{VHB}$ conference in Bremen and of the 2010 BuR conference in Mannheim for helpful and constructive feedback on our paper. Most valuable support has once again been provided by Peter Schmidt. Finally, we would also like to thank the anonymous reviewers for their constructive remarks addressing pitfalls in the earlier version of our paper.

\section{References}

Angelkort, Hendrik (2010): Integration des Rechnungswesens als Erfolgsfaktor für die Controllerarbeit: Eine empirische Untersuchung deutscher Großunternehmen, Lang: Frankfurt/Main et al.

Arnegger, Martin and Christian Hofmann (2007): Periodisierung von Erfolgskomponenten zur Steuerung langfristiger Aufträge, Zeitschrift für Betriebswirtschaft, 77 (2): 115-139.
Bagozzi, Richard P. (1994): Structural Equation Models in Marketing Research: Basic Principles, in: Richard P. Bagozzi (ed.): Principles of Marketing Research, Blackwell: Cambridge, 317385 .

Bagozzi, Richard P. and Youjae Yi (1988): On the Evaluation of Structural Equation Models, Journal of the Academy of Marketing Science, 16 (1): 74-94.

Belkaoui, Ahmed (1978): Linguistic Relativity in Accounting, Accounting, Organizations and Society, 3 (2): 97-104.

Berlant, Debbie, Reese Browning, and George Foster (1990): How Hewlett Packard Gets Numbers It Can Trust, Harvard Business Review, 68 (1): 178-182.

Bollen, Kenneth A. (1989): Structural Equations With Latent Variables, Wiley: New York, NY.

Bollen, Kenneth A. and Richard Lennox (1991): Conventional Wisdom on Measurement: A Structural Equation Perspective, Psychological Bulletin, 110 (2): 305-314.

Browne, Michael W. and Robert Cudeck (1993): Alternative Ways of Assessing Model Fit, in: Kenneth A. Bollen and J. Scott Long (eds.): Testing Structural Equation Models, Sage: Newbury Park, CA, 136-162. 
Bruns, William J. Jr. and Sharon M. McKinnon (1993): Information and Managers: A Field Study, Journal of Management Accounting Research, 5 (1): 84-108.

Byrne, Barbara M. (1989): A Primer of LISREL: Basic Applications and Programming for Confirmatory Factor Analytic Models, Routledge: New York, NY et al.

Byrne, Barbara M. (2009): Structural Equation Modeling With AMOS: Basic Concepts, Applications and Programming, $2^{\text {nd }}$ ed., Routledge: New York, NY et al.

Chandler, Daniel (2007): Semiotics: The Basics, $2^{\text {nd }}$ ed., Routledge: New York, NY et al.

Choe, Jong-Min (1998): The Effects of User Participation on the Design of Accounting Information Systems, Information and Management, 34 (3): 185-198.

Chwolka, Anne (1996): Controlling als ökonomische Institution: Eine agency-theoretische Analyse, Physica: Heidelberg.

Clark, John Maurice (1923): Studies in the Economics of Overhead Costs, University of Chicago Press: Chicago, IL.

Daft, Richard L. and John C. Wiginton (1979): Language and Organization, Academy of Management Review, 4 (2): 179-191.

Davis, Tim R. V. and Lance P. McLaughlin (2009): Is Finance a Business Partner Yet?, Strategic Finance, 90 (3): 35-40.

Demski, Joel S. and Gerald A. Feltham (1976): Cost Determination: A Conceptual Approach, Iowa State University Press: Ames, IA.

Diamantopoulos, Adamantios (2006): The Error Term in Formative Measurement Models: Interpretation and Modeling Implications, Journal of Modelling in Management, 1 (1): 7-17.

Ewert, Ralf (2006): Fair Values und deren Verwendung im Controlling, in: Alfred Wagenhofer (ed.): Controlling und IFRSRechnungslegung, Schmidt: Berlin, 21-48.

Ewert, Ralf and Alfred Wagenhofer (2007): Management Accounting Theory and Practice in German-Speaking Countries, in: Christopher S. Chapman, Anthony G. Hopwood, and Michael D. Shields (eds.): Handbook of Management Accounting Research Vol. 2, Elsevier: Amsterdam et al., 1035-1069.

Festinger, Leon (1957): A Theory of Cognitive Dissonance, Stanford University Press: Stanford, CA.

Fornell, Claes and David F. Larcker (1981): Evaluating Structural Equation Models With Unobservable Variables and Measurement Error, Journal of Marketing Research, 18 (1): 39-50.

Granlund, Markus and Kari Lukka (1998): Towards Increasing Business Orientation: Finnish Management Accountants in a Changing Cultural Context, Management Accounting Research, 9 (2): 185-211.

Haried, Andrew A. (1972): The Semantic Dimensions of Financial Statements, Journal of Accounting Research, 10 (2): 376-391.

Harman, Harry H. (1967): Modern Factor Analysis, $2^{\text {nd }}$ ed., University of Chicago Press: Chicago, IL.

Hopper, Trevor M. (1980): Role Conflicts of Management Accountants and Their Position Within Organizations Structures, Accounting, Organizations and Society, 5 (4): 401-411.

Hopwood, Anthony G. (1974): Accounting and Human Behavior, Haymarket: London.
Hronsky, Jane F. and Keith A. Houghton (2001): The Meaning of a Defined Accounting Concept: Regulatory Changes and the Effect on Auditor Decision Making, Accounting, Organizations and Society, 26 (2): 123-139.

$\mathrm{Hu}, \mathrm{Li}-\mathrm{Tze}$ and Peter M. Bentler (1995): Evaluating Model Fit, in: Rick H. Hoyle (ed.): Structural Equation Modeling: Concepts, Issues, and Applications, Sage: Thousand Oaks, CA, 76-99.

Ijiri, Yuji, Robert K. Jaedicke, and Kenneth E. Knight (1966): The Effects of Accounting Alternatives on Management Decisions, in: Robert K. Jaedicke, Yuji Ijiri, and Oswald Nielsen (eds.): Research in Accounting Measurement, American Accounting Association: Chicago, IL, 186-199.

Indjejikian, Raffi J. and Michal Matějka (2006): Organizational Slack in Decentralized Firms: The Role of Business Unit Controllers, Accounting Review, 81 (4): 849-872.

Jain, Tribhowan N. (1973): Alternative Methods of Accounting and Decision Making: A Psycho-Linguistical Analysis, Accounting Review, 48 (1): 95-104.

Järvenpää, Marko (2007): Making Business Partners: A Case Study on How Management Accounting Culture Was Changed, European Accounting Review, 16 (1): 99-142.

Johnson, H. Thomas and Robert S. Kaplan (1987): Relevance Lost: The Rise and Fall of Management Accounting, Harvard Business School: Boston, MA.

Jones, T. Colwyn and Robert Luther (2005): Anticipating the Impact of IFRS on the Management of German Manufacturing Companies: Some Observations From a British Perspective, Accounting in Europe, 2 (1): 165-193.

Joseph, Nathan, Stuart Turley, John Burns, Linda Lewis, Robert Scapens, and Alan Southworth (1996): External Financial Reporting and Management Information: A Survey of U.K. Management Accountants, Management Accounting Research, 7 (1): 73-93.

Kumar, Nirmalya, Louis W. Stern, and James C. Anderson (1993): Conducting Interorganizational Research Using Key Informants, Academy of Management Journal, 36 (6): 1633-1651.

Maas, Victor S. and Michal Matějka (2009): Balancing the Dual Responsibilities of Business Unit Controllers: Field and Survey Evidence, Accounting Review, 84 (4): 1233-1253.

Müller, Martin (2006): Harmonisierung des externen und internen Rechnungswesens, Gabler: Wiesbaden.

Nunnally, Jum C. and Ira H. Bernstein (1994): Psychometric Theory, $3^{\text {rd }}$ ed., McGraw-Hill: New York, NY.

Pierce, Bernard and Tony O’Dea (2003): Management Accounting Information and the Needs of Managers: Perceptions of Managers and Accountants Compared, British Accounting Review, 35 (3): 257-290.

Pfaff, Dieter (1995): Der Wert von Kosteninformationen für die Verhaltenssteuerung in Unternehmen, Schmalenbachs Zeitschrift für betriebswirtschaftliche Forschung, 34 (Special Issue), 119156.

Ployhart, Robert E. and Frederick L. Oswald (2004): Applications of Mean and Covariance Structure Analysis: Integrating Correlational and Experimental Approaches, Organizational Research Methods, 7 (1): 27-65.

Robey, Daniel (1979): User Attitudes and Management Information System Use, Academy of Management Journal, 22 (3): 527-538. 
Sathe, Vijay (1982): Controller Involvement in Management, Prentice-Hall: Englewood Cliffs, NJ.

Schäffer, Utz (2007): Management Accounting and Control Scales Handbook, Deutscher Universitäts-Verlag: Wiesbaden.

Schermelleh-Engel, Karin, Helfried Moosbrugger, and Hans Müller (2003): Evaluating the Fit of Structural Equation Models: Tests of Significance and Descriptive Goodness-of-Fit Measures, Methods of Psychological Research Online, 8 (2): 23-74.

Schweitzer, Marcell and Ulrich Ziolkowski (eds.) (1999): Interne Unternehmensrechnung: Aufwandsorientiert oder kalkulatorisch?, Schmalenbachs Zeitschrift für betriebswirtschaftliche Forschung, 42 (Special Issue).

Schultz, Randall L. and Dennis P. Slevin (1975): Implementation and Organizational Validity: An Empirical Investigation, in: Randall L. Schultz and Dennis P. Slevin (eds.): Implementing Operations Research/Management Science, American Elsevier: New York, NY et al., 153-182.

Shields, Michael D. (1995): An Empirical Analysis of Firms' Implementation Experiences With Activity-Based Costing, Journal of Management Accounting Research, 7 (1): 148-166.

Siegel, Gary and James E. Sorensen (1999): Counting More, Counting Less: Transformations in the Management Accounting Profession. The 1999 Practice Analysis of Management Accounting, Institute of Management Accountants: Montvale, NJ.

Simons, Dirk and Barbara E. Weißenberger (2008): Die Konvergenz von externem und internem Rechnungswesen: Kritische Faktoren für die Entwicklung einer partiell integrierten Rechnungslegung aus theoretischer Sicht, Betriebswirtschaftiche Forschung und Praxis, 60 (2): 137-160.

Simons, Dirk and Barbara E. Weißenberger (2010): Integration von externer und interner Rechnungslegung: State-of-the-Art und Zukunftsperspektiven nach 15 Jahren betriebswirtschaftlicher Diskussion, Die Betriebswirtschaft, 70 (4): 271-280.

Steenkamp, Jan-Benedict E. M. and Hans Baumgartner (1998): Assessing Measurement Invariance in Cross-National Consumer Research, Journal of Consumer Research, 25 (1): 78-90.

Steinmetz, Holger, Peter Schmidt, Andrea Tina-Booh, Siegrid Wieczorek, and Shalom H. Schwartz (2009): Testing Measurement Invariances Using Multigroup CFA: Differences Between Educational Groups in Human Values Measurement, Quality and Quantity, 43 (4): 599-616.

Tait, Peter and Iris Vessey (1988): The Effect of User Involvement on System Success: A Contingency Approach, MIS Quarterly, 12 (1): 91-108.

Trahan, Emery A. and Lawrence J. Gitman (1995): Bridging the Theory-Practice Gap in Corporate Finance: A Survey of Chief Financial Officers, Quarterly Review of Economics and Finance, 35 (1): $73-87$.
Wagenhofer, Alfred (1996): Vorsichtsprinzip und Managementanreize, Schmalenbachs Zeitschrift für betriebswirtschaftiche Forschung, 48 (12): 1051-1075.

Weaver, Samuel C. (2001): Measuring Economic Value Added: A Survey of the Practices of EVA Proponents, Journal of Applied Finance, 11 (1): 50-60.

Weber, Jürgen and Utz Schäffer (2008): Introduction to Controlling, Schäffer-Poeschel: Stuttgart.

Weißenberger, Barbara E. (1997): Die Informationsbeziehung zwischen Management und Rechnungswesen, Gabler: Wiesbaden.

Weißenberger, Barbara E., IGC-Arbeitskreis „Controller und IFRS“ (2006): Controller und IFRS: Konsequenzen einer IFRSFinanzberichterstattung für die Aufgabenfelder von Controllern, Betriebswirtschaftliche Forschung und Praxis, 58 (4): 342-364.

Weißenberger, Barbara E. and Hendrik Angelkort (2011): Integration of Financial and Management Accounting Systems: The Mediating Influence of a Consistent Financial Language on Controllership Effectiveness, Management Accounting Research, 22 (3): $160-180$

Weygandt, Jerry J., Donald E. Kieso, and Paul D. Kimmel (2005): Managerial Accounting: Tools for Business Decision-Making, $3^{\text {rd }}$ ed., Wiley: Hoboken, NJ.

Ziegler, Hasso (1994): Neuorientierung des internen Rechnungswesens für das Unternehmens-Controlling im Hause Siemens, Schmalenbachs Zeitschrift für betriebswirtschaftliche Forschung, 46 (2): 175-188.

\section{Biographies}

Barbara E. Weißenberger has been Professor and the Chair of Controlling and Business Accounting at the Justus Liebig University Gießen since 2002. She received her Doctoral Degree in 1996 and her Habilitation in 2002 at the WHU Otto Beisheim School of Management. She currently holds the position of Chairperson of the Accounting section of the German Academic Association for Business Research. Her main areas of research are management accounting and control, including the convergence of internal and external accounting systems.

Hendrik Angelkort was a research associate at the same chair from 2005 until 2009. He received his Diploma in Business Administration in 2005 and his Doctoral Degree in 2010 both at the Justus Liebig University Gießen. His dissertation on the convergence of internal and external accounting systems has been awarded the Justus Liebig dissertation prize in 2010. Currently he is working in the controlling department of a DAX-30 company.

Gero Holthoff is a research associate at the same chair since 2009. He received his Diploma in Business Administration in 2009 at the Justus Liebig University Gießen. His research interests focus on the links between accounting and linguistic theory. 